\title{
Peran Orangtua dan Guru dalam Membangun Internet sebagai Sumber Pembelajaran
}

\section{The Role of Parents and Teachers in Building the Internet as a Source of Learning}

\author{
Saifuddin Chalim ${ }^{1}$ dan E. Oos M. Anwas ${ }^{2}$ \\ ${ }^{1}$ Universitas Islam Negeri Sunan Ampel, Surabaya \\ ${ }^{2}$ Pusat Kurikulum dan Perbukuan Balitbang Kemendikbud, Jakarta
}

\begin{abstract}
The reality of the behavior of children and adolescents today is already influenced by the internet. Family and school environments are required to be conducive in getting them to use the internet positively, especially for learning. This study aims to find out: 1) the behavior of students in using the internet; 2) the role of parents and teachers in building the Internet as a source of learning ; and 3) related factors to the intensity of Internet use for learning. This research uses descriptive correlation method, to students of Islamic Senior Hight School 4 Jakarta and Islamic Junior Hight School 3 Jakarta. The sample were taken with simple random sampling, as many as 108 respondents from the population of 1,877 people. The result of data descriptions and correlation test are known that all students every day on average use the internet more than two hours. The use of internet for learning purposes is sufficiently high, significantly related to the concern of parents in guiding their children to learn and control internet usage, the intensity of teachers using the internet, the level of education of parents (mother), and the intensity of students reading textbooks. Using social media, playing games online, using the internet despite the high intensity but not related to the use of the Internet for learning. The implication is that parents and teachers are required to more concerned about learners in using the internet for learning.
\end{abstract}

Keywords: internet, parents, teachers, internet for learning.

\begin{abstract}
Abstrak
Realitas perilaku anak-anak dan remaja masa kini sudah dipengaruhi oleh internet. Lingkungan keluarga dan sekolah dituntut kondusif dalam membiasakan mereka menggunakan internet secara positif terutama untuk pembelajaran. Penelitian ini bertujuan untuk menjelaskan:1) perilaku siswa dalam menggunakan internet; 2) peran orangtua dan guru dalam membangun internet sebagai sumber pembelajaran; dan 3) faktor-faktor yang berhubungan dengan intensitas penggunaan internet untuk pembelajaran. Penelitian ini menggunan metode deskriptif korelasional, terhadap siswa Madrasah Aliyah Negeri 4 Jakarta dan Madrasah Tsanawiyah Negeri 3 Jakarta. Sampel diambil dengan teknik acak sederhana (simple random sampling), sebanyak 108 responden dari populasi sejumlah 1.877 orang. Hasil deskripsi data dan uji korelasi diketahui bahwa semua siswa setiap hari rata-rata menggunakan internet lebih dari dua jam. Penggunaan internet untuk keperluan pembelajaran cukup tinggi, berhubungan signifikan dengan kepedulian orangtua dalam membimbing anaknya belajar dan mengontrol penggunaan internet, intensitas guru menggunakan internet, tingkat pendidikan orangtua (ibu), serta intensitas siswa membaca buku pelajaran. Menggunakan media sosial, bermain game online, menggunakan internet walaupun intensitasnya tinggi tetapi tidak berhubungan dengan penggunaan internet untuk pembelajaran. Implikasinya bahwa orangtua dan guru dituntut lebih peduli terhadap peserta didik dalam memanfaatkan internet untuk pembelajaran.
\end{abstract}

Kata kunci: internet, orangtua siswa, guru, internet untuk pembelajaran

\section{Pendahuluan}

Internet sudah mempengaruhi hampir dalam semua aspek kehidupan manusia. Rasanya belum lama media seperti surat kabar, majalah, radio, dan televisi merupakan sumber informasi yang paling efektif. Realitas kini media seperti facebook, youtube, twitter, instagram, whatsapp, dan sejenisnya menjadi media komunikasi dan informasi yang paling digemari. Tempat perbelanjaan yang menawarkan berbagai fasilitas mewah, kini terancam gulung tikar akibat berkembangnya penjualan online. Alat transfortasi umum Ojek yang dulu dipandang sebelah mata, kini menjadi transportasi online yang trend bagi semua kalangan. Begitupun aspek kehidupan lainnya terus berkembang dan berinovasi sebagai akibat tuntutan perubahan zaman terutama teknologi internet.

Teknologi ineternet juga berdampak terhadap perilaku dan kehidupan generasi masa kini. Anak-anak masa kini begitu akrab dengan internet melalui berbagai perangkat gawai, seperti: komputer, laptop, tablet, handphone, smartphone, dan perangkat

\footnotetext{
${ }^{1}$ Korespondensi penulis

E-mail: oos.anwas@kemdikbud.go.id
} 
sejenisnya. Kehidupan mereka mulai dari; bermain, berkomunikasi, bergaul, menyalurkan hobby, dan aspek-aspek lainnya tidak terlepas dari teknologi internet. Namun satu hal yang disayangkan adalah internet masih sangat kecil digunakan untuk keperluan pembelajaran. Hasil studi yang dilakukan oleh TechinAsia (2015) menunjukkan bahwa pengguna internet di Indonesia dominan untuk mencari berita dan hiburan, bahkan untuk konten pendidikan hanya 5\% saja. Begitupun acara televisi yang digemari oleh pemirsa dominan bernuansa hiburan dan informasi (Kusuma dan Hardiyanto, 2015).

Anak-anak dan remaja tidak bisa dicegah untuk tidak memanfaatkan internet. Yang bijaksana adalah mengarahkan mereka untuk pemanfaatan internet untuk kegiatan positif, misalnya untuk pendidikan dan menambah ilmu pengetahuan. Pengaruh lingkungan sangat penting dalam menciptakan pembiasaan, menggunakan pemanfaatan internet untuk pendidikan.

Lingkungan ini terutama di lingkungan keluarga dan lingkungan sekolah yang relatif mudah dikontrol oleh orangtua dan guru. Hasil penelitian Unicef bekerjasama dengan Kementerian Komunikasi dan Informatika (Kominfo, 2014), menunjukkan bahwa pola komunikasi pada anak dan remaja melalui internet yang pengaruhnya signifikan adalah mayoritas dilakukan dengan teman sebaya, diikuti komunikasi dengan guru, dan komunikasi dengan anggota keluarga.

Dalam lingkungan keluarga, peran orangtua sangat penting untuk menciptakan lingkungan yang kondusif agar anak-anak memanfaatkan internet secara positif. Begitu pula pada lingkungan sekolah, peran guru memiliki peran penting untuk membimbing dan mengarahkan siswa agar mampu memanfaatkan internet untuk keperluan pembelajaran. Inilah tuntutan sekolah pada era masa kini tidak bisa lepas dari internet.

Hasil-hasil penelitian tentang pengaruh internet dalam berbagai kehidupan manusia sudah banyak dilakukan. Fahriantini (2016) melakukan pentingnya peran orangtua dalam mengawasi anakanak dalam penggunaan gawai. Fitri (2017) meneliti tentang dampak positif dan negatif media terhadap perubahan sosial anak. Ulinnuha (2013) meneliti tentang bagaimana melindungi anak dari konten negatif internet. Studi tentang manfaat internet untuk pembelajaran juga sudah banyak dilakukan. Aberg dkk (2016) menemukan bahwa menggunakan sumber belajar digital dapat meningkatkan kemampuan dalam menulis peserta didik. Hasil penelitian John dkk (2016) menunjukkan bahwa belajar secara online dapat meningkatkan interaksi dan keterlibatan peserta didik.

Penelitian-penelitian yang menjelaskan bagaimana menciptakan pemanfaatan internet untuk pendidikan masih sangat jarang dilakukan. Begitupun bagaimana peran orangtua dan guru dalam membangun kebiasaan anak untuk memanfaatkan internet untuk pembelajaran masih belum dilakukan. Peran orangtua dan guru ini sangat penting, karena mereka adalah orang yang berhadapan langsung dengan anak-anak di lingkungan keluarga dan sekolah.

Kondisi tersebut menarik untuk dilakukan penelitian bagaimana peran orangtua dan guru dalam membangun lingkungan yang kondusif agar anak dapat memanfaatkan internet untuk pembelajaran. Oleh karena itu penelitian ini bertujuan untuk menjelaskan: 1) perilaku siswa dalam menggunakan internet; 2) peran orangtua dan guru dalam membangun perilaku siswa menggunakan internet sebagai sumber pembelajaran; dan 3) faktor-faktor yang berhubungan dengan intensitas siswa dalam penggunaan internet untuk pembelajaran.

\section{Metode Penelitian}

Penelitian ini menggunakan pendekatan kuantitatif, dengan metode deskriptif korelasional. Penelitian dilakukan di Madrasah Aliyah Negeri 4 Jakarta dan Madrasah Tsanawiyah Negeri 3 Jakarta. Sekolah ini sudah memiliki kepedulian terhadap keberadaan internet. Di sisi lain, sebagai sekolah madrasah, selain memiliki pelajaran umum di SMP dan SMA juga ada tambahan pelajaran yang berbasis agama Islam. Mata pelajaran tambahan tersebut di antaranya: Fiqih, Hadish, Bahasa Arab, Sejarah Islam, hapalan Al-Quran, dan mata pelajaran sejenisnya. Tuntutan jumlah mata pelajaran tersebut menambah intensitas belajar siswa. Dengan kata lain, tuntutan belajar peserta pada madrasah lebih tinggi dibandingkan dengan pada sekolah umum. Tingginya tuntutan belajar tersebut, mengurangi kesempatan anak untuk bermain, termasuk melalui internet.

Pengumpulan data dilakukan terhadap siswa Madrasah Aliyah Negeri 4 Jakarta dan Madrasah 
Tsanawiyah Negeri 3 provinsi Daerah Khusus Ibu kota (DKI) Jakarta. Jumlah populasi tersebut sebanyak 1.877 siswa. Populasi diasumsikan relatif homogen, sehingga sampel diambil dengan teknik acak sederhana (simple random sampling). Dengan teknik sampling tersebut diperoleh sampel sebanyak 108 siswa.

Peubah yang diteliti adalah perilaku siswa dalam menggunakan internet, peran orangtua dan guru dalam membangun perilaku siswa menggunakan internet sebagai sumber pembelajaran, dan faktorfaktor yang berhubungan dengan intensitas siswa dalam penggunaan internet untuk pembelajaran. Perilaku siswa dalam menggunakan internet meliputi intensitas pengguaan internet, aspek yang diperlukan dalam menggunakan internet, serta intensitas penggunaan internet untuk mencari bahan-bahan pembelajaran.

Peran orangtua dalam membangun perilaku siswa menggunakan internet sebagai sumber pembelajaran meliputi aspek intensitas membimbing anaknya dalam belajar dan intensitas mengontrol penggunaan internet.

Peran guru dalam membangun perilaku siswa menggunakan internet sebagai sumber pembelajaran adalah intensitas memberikan tugastugas pelajaran dengan memanfaatkan internet. Faktor-faktor yang diduga berhubungan dengan intensitas siswa dalam penggunaan internet untuk pembelajaran adalah: tingkat pendidikan orangtua (ayah dan ibu), intensitas kontrol orangtua siswa dalam menggunakan internet, intensitas bimbingan orangtua dalam belajar, intensitas guru memberikan tugas-tugas pelajaran untuk memanfaatkan internet, intensitas siswa membaca buku pelajaran, intensitas menggunakan media sosial, intensitas bermain game online dan intensitas penggunaan internet.

Alat pengumpulan data berupa kuestioner tertutup. Data kuesioner diperoleh berdasarkan pendapat para siswa, termasuk data tentang peran orangtua dan gurunya. Untuk memperkaya data kuantitatif, dilakukan wawancara secara mendalam (indepth interview) terhadap beberapa siswa, guru, dan orangtua siswa.

Pelaksanaan pengumpulan data dilakukan pada bulan November 2017. Data diolah dengan statistik deskriptif dan uji korelasi Spearman. Untuk memudahkan pengolahan data digunakan aplikasi SPSS versi 23.

\section{Hasil dan Pembahasan}

\section{Perilaku Siswa dalam Menggunakan Internet}

Genarasi masa kini disebut sebagai generasi digital native. Kondisi tersebut nampak benar apabila memperhatikan Tabel 1. Tabel ini menunjukkan bahwa tidak ada satupun siswa yang menyatakan tidak pernah menggunakan internet khususnya telephone seluler (Ponsel).

\section{Tabel 1 Frekuensi Rata-rata Penggunaan Internet Dalam Sehari}

\begin{tabular}{clcr}
\hline No & $\begin{array}{c}\text { Frekuensi } \\
\text { Penggunaan }\end{array}$ & Jumlah & \% \\
\hline 1 & Tidak Pernah & 0 & 0 \\
2 & $<1$ jam & 15 & 13,9 \\
3 & 1 s.d. 2 jam & 31 & 28,7 \\
4 & $>2$ jam & 62 & 57,4 \\
\hline Total & $\mathbf{1 0 8}$ & $\mathbf{1 0 0}$ \\
\hline
\end{tabular}

Dalam Tabel 1, sebagian besar siswa menggunakan gawai lebih dari dua jam setiap hari, hanya sebagian kecil saja atau $13,9 \%$ yang penggunaannya kurang dari satu jam. Artinya setiap hari siswa tidak pernah lepas dari penggunaan internet. Mereka sudah terbiasa menggunakan berbagai perangkat gawai khususnya ponsel. Tabel tersebut menunjukkan bahwa generasi masa kini aktivitas setiap hari tidak bisa lepas dari yang berbagai produk gadget terutama handphone/smartphone. Menurut data Globalwebindex (Youthmanual, 2017), pengguna smartphone seluruh dunia terus meningkat dan jumlahnya sudah mencapai 3.4 milyar. Ini artinya, 93\% dari pengguna internet secara keseluruhan beralih menggunakan smartphone daripada laptop atau personal computer. Hal ini disebabkan kapasitas dan teknologi smartphone makin meningkat, penggunaannya lebih praktis dan fleksibel, serta harganya makin terjangkau oleh berbagai lapisan masyarakat.

Tabel 2 menjelaskan bahwa siswa menggunakan internet dari berbagai piranti gawai untuk keperluan beragam. Tidak satupun siswa yang memilih satu keperluan saja dalam penggunaan internet. Semua siswa memilih jawaban lebih dari satu pilihan. Tabel 2 menunjukkan bahwa penggunaan 
media sosial merupakan peringkat paling tinggi, yaitu $74,1 \%$, kemudian diikuti dengan mencari bahanbahan pelajaran sebesar $72,2 \%$, mencari berita atau informasi sebesar 70,4\%, bermain game sebesar $65,70 \%$, serta keperluan lain-lain sebesar $13 \%$.

Tabel 2. Internet Digunakan untuk Keperluan Beragam

\begin{tabular}{clcc}
\hline No & \multicolumn{1}{c}{ Keperluan Internet } & Jumlah & $\mathbf{\%}$ \\
\hline 1 & Mengunakan sosial media & 80 & 74,1 \\
2 & Mencari bahan/sumber pelajaran & 78 & 72,2 \\
3 & Mencari berita/informasi & 76 & 70,4 \\
4 & Bermain game & 71 & 65,7 \\
5 & Lain-lain & 14 & 13,0 \\
\hline
\end{tabular}

Penggunaan media sosial merupakan peringkat tertinggi dalam pemanfaatan internet. Hal ini sejalan dengan kecenderungan di masyarakat. Realitas umumnya masyarakat sangat gemar menggunakan media sosial seperti: facebook, whats App, twitter, instagram, dan sejenisnya. Berdasarkan data yang dioleh dari Global web index (Youth manual, 2017), jumlah pengguna internet di dunia lebih dari 3,8 milyar orang, dengan sebanyak 2,9 milyar aktif menggunakan media sosial. Jadi penduduk dunia kini memang sedang trend menggunakan media sosial. Khusus di Indonesia, pengguna media sosial khususnya penggunaan facebook menempati peringkat keempat terbesar dunia, setelah negara Amerika Serikat, India, dan Brazil.

Bagaimana pengaruh tingginya intensitas penggunaan media sosial terhadap perilaku remaja. Hasil penelitian Juwita dkk. (2015) terhadap siswa SMA di kota Bandung Jawa Barat bahwa penggunaan media sosial berdampak positif dan negatif terhadap remaja, terutama berpengaruh terhadap gaya hidup remaja, digunakan sebagai alat komunikasi maupun hiburan dikalangan remaja perkotaan. Hasil penelitian Al-Dheleal dan Zaidatun (2017) menemukan bahwa siswa memiliki pandangan positif terhadap penggunaan facebook untuk interaksi online dengan teman sebayanya.

Pergaulan melalui media sosial sudah menjadi trend masa kini. Mereka bergaul dan berkomunikasi dengan sesamanya dapat menembus geografis bahkan melintas samudra. Pergaulan dan pertemanan melalui media sosial ini tidak jarang secara fisik belum mengenal dan bertemu, namun melalui media sosial bisa lebih akrab. Media sosial juga dimanfaatkan untuk menyalurkan hobi, seperti bermain game, bernyanyi, bermain musik, olahraga, dan bentu lainnya. Begitupun media sosial sudah banyak digunakan untuk berbelanja dan melakukan berbagai bisnis online termasuk pada kalangan remaja. Hasil penelitian Nugraha (2015) menunjukkan bahwa penyebab siswa menggunakan media sosial sebagai: pengaruh dari teman-temannya, sebagai sarana gaul/ pertemanan, dan media sosial digunakan sebagai wahana aktualisasi diri, serta tujuan utama siswa menggunakan media sosial adalah untuk mendapatkan pengakuan sosial. Ini artinya dorongan utama siswa/ remaja menggunakan media sosial adalah merupakan tuntutan nyata pergaulan masa kini di era digital native.

Temuan yang menarik dari penelitian ini (Tabel 1), menunjukkan bahwa tingginya siswa penggunaan internet untuk keperluan mencari sumber atau bahan-bahan pelajaran, yaitu sebesar $72,2 \%$. Hasil wawancara dengan beberapa siswa menyatakan mereka sudah terbiasa mencari bahanbahan pelajaran dari internet. Mereka juga paham beberapa search engine yang sering digunakan untuk mencari materi-materi pelajaran sekolah. Responden memiliki kesadaran dan pemahaman bahwa internet bukan sekedar untuk hiburan dan komunikasi saja, tetapi dapat digunakan untuk meningkatkan prestasi belajarnya. Internet sudah dimanfaatkan untuk pembelajaran secara baik. Padahal dalam banyak studi yang dilakukan sebelumnya bahwa penggunaan internet melalui berbagai gawai, dominan digunakan untuk keperluan hiburan dan komunikasi saja (Anwas, 2016), (TechinAsia, 2015).

\section{Peran orangtua dan guru dalam membangun perilaku siswa menggunakan internet}

Pada Tabel 3 menunjukkan bahwa sebagian besar (61,2 persen) guru-guru sering memberikan tugas-tugas pelajaran menggunakan internet. Tugastugas tersebut ada yang diberikan melalui internet atau ada yang dalam pengerjaanya perlu mencari bahanbahan melalui internet. Tidak ada satu siswapun yang menyatakan gurunya tidak pernah memberikan tugas pelajaran yang berkaitan dengan penggunaan internet. Ini artinya para siswa sudah dibiasakan oleh gurugurunya menggunakan internet untuk pembelajaran. 
Tabel 3. Frekuensi Guru Memberikan Tugas Pelajaran Menggunakan Internet

\begin{tabular}{llrr}
\hline No & $\begin{array}{c}\text { Frekuensi tugas } \\
\text { pelajaran }\end{array}$ & Jumlah & \% \\
\hline 1 & Tidak Pernah & 0 & 0,0 \\
2 & Jarang & 42 & 38,9 \\
3 & Sering & 64 & 59,3 \\
4 & Selalu & 2 & 1,9 \\
\hline Total & 108 & 100,0 \\
\hline
\end{tabular}

Hasil wawancara dengan guru dan siswa bahwa memang di kedua sekolah ini anak-anak tidak diperbolehkan menggunakan gawai di sekolah. Aturan yang digunakan di sekolah adalah setiap masuk kelas, siswa yang membawa handphone wajib dikumpulkan di meja guru. Pada saat pulang sekolah dikembalikan lagi kepada siswa, begitu seterusnya. Handphone tersebut penting untuk komuniksi siswa dengan orangtua terutama saat penjemputan atau komunikasi penting lainnya. Namun sekolah melalui guru-gurunya memiliki kepedulian dalam memanfaatkan internet untuk pembelajaran. Mereka dibiasakan menggunakan internet untuk mendukung pembelajaran, melalui tugas-tugas dan bentuk pengayaan lainnya.

Upaya pembiasaan penggunaan internet/ ponsel untuk keperluan pembelajaran, ternyata berdampak terhadap sumber belajar yang sering digunakan siswa, seperti dijelaskan dalam Tabel 4.

Tabel 4. Penggunaan Sumber Belajar dalam Mengerjakan Tugas Sekolah

\begin{tabular}{llrr}
\hline No & \multicolumn{1}{c}{ Sumber/ Media } & Jumlah & \% \\
\hline 1 & Internet & 101 & 93,5 \\
2 & Buku & 78 & 72,2 \\
3 & Bimbingan orangtua & 64 & 59.3 \\
4 & Televisi & 4 & 3,7 \\
5 & Radio & 0 & 0,0 \\
6 & Sumber lain & 0 & 0,0 \\
\hline
\end{tabular}

Tabel 4 menjelaskan adanya perubahan penggunaan sumber belajar pada genarasi masa kini yang sering disebut sebagai generasi digital native. Generasi sebelumnya, sumber belajar utama adalah buku (buku cetak konvensional). Sebagai sumber belajar utama, pada masa itu buku dijuluki sebagai gudangnya ilmu. Namun generasi masa kini pada Tabel 4 menjelaskan bahwa hampir seluruhnya siswa ketika mengerjakan tugas-tugas pelajaran sekolah menggunakan internet. Ini adalah tuntutan perubahan zaman. Saat ini sebagian buku juga sudah dibuat versi digital. Buku-buku teks pelajaran utama terbitan Kementerian Pendidikan dan Kebudayaan semuanya dibuat dalam versi digital yang bisa diakses melalui laman http://buku.kemdikbud.go.id.

Televisi juga digunakan sebagian kecil siswa $(3,7 \%)$ sebagai sumber belajar. Tidak ada satupun siswa yang menggunakan radio sebagai sumber belajar. Media televisi dan radio pada era digital ini sistem deliverinya tidak hanya mengandalkan broadcash melalui frekuensi tertentu, tetapi sudah menggunakan teknologi internet. Beberapa siswa yang diwawancarai penulis, menyatakan sering mencari bahan-bahan pelajaran dalam format audio dan video melalui internet. Ini menunjukan bahwa teknologi televisi dan radio jika digunakan untuk pendidikan khususnya sasaran siswa sekolah, wajib belalui teknologi internet. Jika ada stasiun radio atau televisi untuk keperluan pendidikan yang masih menyiarkan dengan teknologi broadcash (menggunakan frekuensi), sudah harus hijrah menggunakan internet. Untuk wilayah tertentu yang belum ada internetnya, lebih efektif menggunakan teknologi offline, misalnya menggunakan kaset audio atau video.

Penggunaan internet menjadi positif terutama untuk keperluan pembelajaran juga tidak terlepas dari peran orangtua siswa. Tabel 4 , juga menunjukkan bahwa lebih dari setengahnya siswa menyatakan pada saat mengerjakan tugas-tugas pelajaran sekolah mendapat bimbingan dari orangtuanya. Data ini menunjukkan adanya kesadaran dari para orangtua untuk mendampingi anak-anaknya, membimbing dalam belajar mereka di rumahnya.

Secara lebih khusus dalam Tabel 5, sebagian besar orangtua siswa sering mengontrol anaknya dalam penggunaan internet. Hanya sebagian kecil saja orangtua yang tidak peduli terhadap penggunaan internet anaknya. Ini artinya para orangtua memiliki kesadaran dan kepedulian tinggi dalam mengontrol anaknya menggunakan internet. Hasil wawancara dengan beberapa siswa, bentuk kontrol dari orangtua adalah sering menegur jika sedang bermain game online. Sebagian anak bahkan menceritakan 
orangtuanya yang sangat peduli terhadap penggunaan Ponsel, ketika sedang mencari bahan-bahan pelajaran melalui Ponsel ditegur oleh orangtuanya. Mereka dikira sedang bermain game atau sedang chating melalui media sosial. Frekuensi kontrol orangtua ini secara tidak sadar membiasakan terhadap anak-anak untuk menggunakan internet pada hal-hal positif terutama pembelajaran.

Tabel 5. Intensitas Orangtua Mengontrol Penggunaan Internet

\begin{tabular}{|c|c|c|c|}
\hline No & Intensitas mengontrol & Jumlah & $\%$ \\
\hline 1 & tidak pernah & 7 & 6,5 \\
\hline 2 & Jarang mengontrol & 17 & 15,7 \\
\hline 3 & Sering mengontrol & 84 & 77,8 \\
\hline 4 & Selalu mengontrol & 0 & 0,0 \\
\hline \multicolumn{2}{|c|}{ Total } & 108 & 100,0 \\
\hline
\end{tabular}

\section{Faktor yang Berhubungan dengan Penggunaan Internet untuk Pembelajaran}

Hasil uji korelasi terhadap peubah-peubah yang diduga berhubungan dengan penggunaan internet sebagai sumber pembelajaran siswa disajikan dalam Tabel 6 . Ada enam peubah yang berhubungan secara positif dan signifikan dengan intensitas siswa dalam penggunaan internet sebagai sumber pembelajaran. Adapun peubah yang berhubungan tersebut, diurutkan dari koefisien yang paling tinggi adalah: 1) intensitas bimbingan orangtua dalam belajar $(\mathrm{r}=0,525)$; 2) intensitas kontrol orangtua terhadap siswa dalam menggunakan internet $(\mathrm{r}=$ $0,358)$; 3) intensitas guru memberikan tugas-tugas pelajaran untuk memanfaatkan internet $(\mathrm{r}=0,282)$; 4) tingkat pendidikan ibu ( $\mathrm{r}=0,203)$; dan 5) intensitas siswa dalam membaca buku pelajaran $(r=0,215)$.

Hasil tersebut memberikan makna bahwa apabila: 1) intensitas bimbingan orangtua dalam belajar; 2) intensitas kontrol orangtua terhadap siswa dalam menggunakan internet; 3) intensitas guru memberikan tugas-tugas pelajaran untuk memanfaatkan internet; 4) tingkat pendidikan ibu; dan 5) intensitas siswa dalam membaca buku pelajaran tinggi atau meningkat, maka pemanfaatan internet sebagai sumber/bahan pembelajaran juga meningkat atau tinggi. Sebaliknya, apabila: 1) intensitas siswa bertanya pada orangtua dalam belajar; 2) intensitas kontrol orangtua terhadap siswa dalam menggunakan internet; 3) intensitas guru memberikan tugas-tugas pelajaran untuk memanfaatkan internet; 4) tingkat pendidikan ibu dari orangtua siswa menurun atau rendah; dan 5) intensitas siswa dalam membaca buku pelajaran, maka pemanfaatan internet sebagai sumber/bahan pembelajaran juga menurun/rendah.

Tabel 6. Hasil Uji Korelasi dengan Penggunaan Internet sebagai Sumber Pembelajaran

\begin{tabular}{|c|c|c|c|}
\hline No & Variabel & $\mathbf{r}$ & sig \\
\hline 1 & $\begin{array}{l}\text { Bimbingan orangtua } \\
\text { dalam belajar }\end{array}$ & .523 & $.000 * *$ \\
\hline 2 & $\begin{array}{l}\text { Kontrol orangtua } \\
\text { penggunaan internet }\end{array}$ & .358 & $.000 * *$ \\
\hline 3 & $\begin{array}{l}\text { Intensitas tugas } \\
\text { pelajaran dari guru }\end{array}$ & .282 & $.003 * *$ \\
\hline 4 & Pendidikan ibu & .203 & $.035 *$ \\
\hline 5 & $\begin{array}{l}\text { Intensitas membaca } \\
\text { buku pelajaran }\end{array}$ & .215 & $.025 *$ \\
\hline 6 & Pendidikan ayah & .171 & .076 \\
\hline 7 & $\begin{array}{l}\text { Bermain game via } \\
\text { internet }\end{array}$ & .119 & .222 \\
\hline 8 & $\begin{array}{l}\text { Penggunaan media } \\
\text { sosial }\end{array}$ & .010 & .914 \\
\hline 9 & $\begin{array}{l}\text { Intensitas menggunakan } \\
\text { internet }\end{array}$ & .173 & .074 \\
\hline
\end{tabular}

Keterangan: $\quad * *$ Signifikan pada $\alpha=0,01$

* Signifikan pada $\alpha=0,05$

Peran orangtua dalam mendidik anak terutama terkait dengan era digital sangat penting. Dalam banyak kajian yang dilakukan sebelumnya bahwa pemanfaatan internet dengan berbagai jenis perangkatnya adalah sebuah keniscayaan. Siapapun termasuk orang tua tidak bisa melarang terhadap anaknya. Yang paling bijaksana adalah mengarahkan agar internet digunakan untuk hal-hal yang positif terutama pembelajaran, meningkatkan prestasi akademik anak-anak. Tabel 6 menunjukkan bahwa peran orangtua sangat penting. Terdapat hubungan yang signifikan dan positif antara intensitas bimbingan orangtua dalam belajar terhadap pemanfaatan internet sebagai sumber belajar. Peran Ini artinya pada era digital sekarang ini, orang tua 
perlu memiliki kesadaran dan melakukan bimbingan anaknya dalam belajar, sekaligus mengarahkan anak bagaimana memanfaatkan internet untuk mendukung kegiatan pembelajaran.

Peran orang tua pada era digital juga dituntut untuk mampu mengawasi dan mengontrol anaknya dalam penggunaan internet. Hal ini terbukti bahwa pemanfaatan internet untuk kegiatan positif terutama untuk pembelajaran berhubungan signifikan dan positif dengan intensitas kontrol orangtua dalam menggunakan internet $(\mathrm{r}=0,358)$. Begitu pula pada Tabel 5 menunjukkan bahwa sebagian besar (77,8\%) orangtua memiliki kepedulian tinggi dalam mengontrol anaknya menggunakan internet. Ini artinya sebagian besar para orangtua sering melakukanpengawasan terhadap pemanfaatan internet anak-anaknya, sehingga berhubungan dengan intensitas pemanfaatan internet untuk keperluan pembelajaran. Hal ini sejalan dengan hasil penelitian Fahriantini (2016) menguatkan pentingnya peran orangtua untuk melibatkan anak berfikir kritis, mengajak anak melakukan diskusi sederhana mengenai kasus-kasus yang timbul akibat kejahatan yang dilakukan di dunia maya.

Mengontrol penggunaan internet tidak harus dilakukan denganketat. Mengontrol atau mengawasi perlu dilakukan secara persuasif dengan tetap menghargai privacy anak. Dalam hal ini hasil penelitian Faisal (2016) menguraikan bahwa mendidik anak di era digital dengan cara menerapkan pola asuh yang tidak otoriter karena anak tidak senang dipaksa melainkan dibujuk dan cenderung dibiarkan namun juga harus tetapd iawasi oleh orang tua. Selain itu orang tua juga harus mampu memahami ragam aplikasi yang mendidik anak dan memandu anak untuk memainkannya dengan baik serta mengawasi penggunaan media informasi tersebut agar tidak menyimpan dari nilai-nilai pendidikan Islam.

Anak-anak dapat memanfaatkan internet melalui banyak varian gawai, misalnya melalui: komputer PC, laptop, hanphone, smartphone, tablet, dan perangkat sejenisnya. Mereka umumnya lebih mudah dan pinter dibandingkan orangtuanya dalam menggunakan internet melalui berbagai perangkat tersebut. Namun sebagai orangtua pada zaman kini, dituntut untuk melek dan mampu mengoperasikan berbagai perangkat gawai yang digunakan oleh anaknya. Hal ini penting agar orangtua mampu mengawasi dan mengontrol perilaku anak-anaknya dalam pemanfaatan internet.

Pemanfaatan internet untuk kegiatan pembelajaran juga berhubungan positif dan signifikan dengan tingkat pendidikan ibunya $(r=0,203)$ (Tabel 6). Tingkat pendidikan memberikan wawasan dan pemahaman tentang manfaat dan bahaya dari media internet terhadap anak-anak. Tingkat pendidikan yang memadai cenderung memahami dan menggunakan teknologi informasi dengan baik (Dasli, dkk, 2015). Oleh karena itu semakin tinggi tingkat pendidikan ibu-ibu maka semakin peduli terhadap anaknya dalam memanfaatkan internet untuk pendidikan. Yang menarik dalam Tabel 6 adalah mengapa tingkat pendidikan para ayah tidak berhubungan signifikan dengan pemanfaatan internet untuk pembelajaran anaknya $(\mathrm{r}=0.171)$ (Tabel 6). Hasil wawancara dengan beberapa orangtua dan guru diketahui bahwa umumnya membimbing anak-anak lebih banyak dipercayakan kepada kaum ibu. Para ayah lebih fokus dalam bekerja. Bahkan beberapa ayah ketika ditanya ternyata tidak sedikit yang tidak tahu anaknya berada di kelas paralel apa, misalnya kelas sepuluh A, kelas sepuluh B, atau kelas mana. Begitupun pada saat acara rapat komite sekolah, yang sering hadir adalah mayoritas ibu-ibu. Ini adalah teguran dan sekaligus tantangan bagi para ayah untuk lebih peduli terhadap pendidikan dan pembelajaran anak-anaknya.

Peran guru terhadap siswa dalam memanfaatkan internet untuk kegiatan pembelajaran sangat penting. Dalam Tabel 6, menunjukkan bahwa intensitas guru memberikan tugas-tugas pelajaran untuk memanfaatkan internet berhubungan positif dan signifikan dengan nilai koefisien korelasi sebesar 0,282 . Ini artinya semakin sering bapak/ibu guru memberikan tugas kepada siswa, mengintegrasikan pembelajaran dengan berbantuan internet, maka secara langsung membiasakan siswa memanfaatkan internet untuk pembelajaran. Pemanfaatan internet untuk pembelajaran sesungguhnya adalah proses mengubah budaya belajar dari semula belajar melalui buku, menuju perangkat digital, yang perlu dilakukan secara bertahap, berkelanjutan menuju proses pembiasaan (Anwas, 2011). Memberikan tugas-tugas kepada siswa merupakan bentuk pembiasaan yang dilakukan guru dalam pemanfaatan internet untuk pembelajaran.

Jika ada asumsi bahwa kekhawatiran penggunaan internet dilakukan dengan cara melarang siswa barangkali keliru. Melarang siswa menggunakan 
internet pada saat proses pembelajaran di kelas mungkin benar, karena bisa menganggu konsentrasi belajar. Tetapi ada saatnya proses pembelajaran perlu bantuan internet, misalnya mengerjakan tugas-tugas, mencari bahan-bahan dalam diskusi, dan kegiatan lainnya.

Memberikan tugas-tugas pembelajaran untuk memanfaatkan internet memiliki kontribusi positif terhadap prestasi belajar siswa.Hasil penelitian Susena dan Amelia (2014) dilakukan terhadap siswa SMA menunjukan bahwa setelah responden disarankan untuk mencari materi pelajaran melalui internet nilainya lebih baik daripada sebelum disarankan untuk mencari materi pelajaran di internet. Sekolah yang memanfaatkan jaringan internet untuk mendukung pembelajaran nilai lebih tinggi dari pada sekolah yang belum memanfaatkan internet sebagai pendukung pembelajaran.

Internet merupakan salah satu jenis media dari sekian banyak jenis media. Seperti hanya buku, dalam internet banyak pesan-pesan pendidikan dan pembelajaran. Siswa yang sering membaca buku teks untuk belajar, maka kehadiran internet dimanfaatkan untuk keperluan belajar pula. Hal ini terbukti dalam penelitian ini. Pada Tabel 6, menunjukkan bahwa intensitas siswa dalam membaca buku pelajaran berhubungan signifikan dan positif dengan pemanfaatan internet sebagai bahan pembelajaran $(\mathrm{r}=0,215)$. Artinya siswa yang rajin membaca buku untuk belajar memiliki kecenderungan memanfaatkan internet untuk belajar. Bahkan dengan kecanggihanya internet lebih menarik dari buku karena dapat menampilan pesan pembelajaran secara multimedia. Pesan pembelajaran dalam internet tidak hanya berbasis teks tetapi juga berbasis audio, video, anmiasi, bahkan simulasi (Anwas, 2016).

Tabel 6 menunjukkan bahwa intensitas bermain game via internet, intensitas penggunaan media sosial, dan intensitas menggunakan internet tidak berhubungan signifikan dengan intensitas pemanfaatan internet untuk pembelajaran. Walaupun dalam Tabel 2 diketahui bahwa intensitas penggunaan media sosial seperti: facebook, whatsApp, twitter, dan sejenisnya cukup tinggi yaitu sebanyak $74 \%$, tetapi tidak berhubungan siginifikan dengan pemanfaatan internet untuk pembelajaran. Intensitas bermain game juga tinggi yaitu sebesar $65,7 \%$ (Tabel 2), tetapi juga tidak berhubungan siginifikan dengan pemanfaatan internet untuk pembelajaran. Begitu pula pada
Tabel 1 menunjukkan bahwa intensitas pemanfaatan internet setiap siswa cukup tinggi yaitu rata-rata di atas dua jam per hari, namun ternyata tidak memiliki hubungan yang signifikan dengan pemanfaatan internet untuk pembelajaran. Ini implikasinya, intensitas penggunaan media sosial, bermain game online, serta intensitas penggunaan internet lainnya pada siswa perlu dikurangi karena ternyata tidak berhubungan signifikan dengan pemanfaatan internet untuk pembelajaran. Sebaliknya peubah-peubah yang memiliki hubungan signifian dengan pemanfaatan internet untuk pembelajaran perlu ditingkatkan.

\section{Kesimpulan}

Perilaku siswa dalam penggunaan internet cukup tinggi, yaitu setiap hari rata-rata lebih dari dua jam. Internet tersebut digunakan untuk keperluan: media sosial, mencari bahan/sumber pelajaran, mencari informasi, dan bermain game. Orangtua siswa memiliki kepedulian tinggi dalam membimbing anak belajar dan mengontrol menggunakan internet. Guruguru sebagian besar sudah terbiasa menggunakan internet untuk mendukung pembelajaran siswanya.

Penggunaan internet untuk keperluan pembelajaran tergolong tinggi. Hal ini berhubungan signifikan dengan tingginya kepedulian orangtua dalam membimbing anak belajar dan mengontrol menggunakan internet, besarnya peran guru dalam menggunakan internet untuk mendukung pembelajaran, tingkat pendidikan orangtua terutama ibu, serta intensitas siswa dalam membaca buku pelajaran. Adapun tingkat pendidikan ayah tidak berhubungan signifikan karena kurangnya perhatian ayah terhadap belajar anak. Menggunakan media sosial, bermain game online, penggunaan internet walaupun intensitasnya tinggi, tetapi tidak berhubungan dengan pemanfaatan internet untuk pembelajaran.

Implikasi dari penelitian ini, para orangtua siswa dituntut lebih peduli terhadap proses belajar anak-anaknya, membimbing anak untuk belajar, membantuataumendampingianakdalammengerjakan tugas-tugas dari sekolah, serta mengontrol anaknya dalam penggunaan internet secara bijaksana. Bagi guru, dituntut untuk melek internet, mengintegrasikan internet dalam pembelajaran, atau memberikan tugastugas dan mencari bahan-bahan pembelajaran melalui internet. Lembaga pendidikan (sekolah dan perguruan 
tinggi) dan masyarakat juga dituntut lebih peduli dan menyadari bahwa media internet tidak hanya sekedar digunakan untuk hiburan dan komunikasi saja, tetapi dapat digunakan untuk meningkatkan kemampuan, meningkatkan kualitas hidup dan kesejahteraan.

\section{Daftar Pustaka}

Aberg ES, Stahle Y, Engdahl I, Nyqvist HK. 2016. Designing a Website to Support Students Academic Writing Process. TOJET: The Turkish Online Journal of Educational Technology, 15(1): 33-42.

Al-Dheleal, Yahya M, Zaidatun T. 2017. Using Facebook for the Purpose of Students' Interaction and its Correlation with Students' Academic Performance. TOJET: The Turkish Online Journal of Educational Technology, 16(4) : 170178. [Internet] dapat diunduh di http://www.tojet. net/articles/v16i4/16416.pdf.

Anwas OM. 2011. Pembudayaan Teknologi Informasi dan Komunikasi di Sekolah. Jurnal Teknodik, Pustekkom Kemendikbud, XV(1) : 75-83.

Anwas OM. 2016. Model Buku Teks Pelajaran berbasis Teknologi Informasi dan Komunikasi. Jurnal Kwangsan BPMTP Surabaya, 4(1) : 1732.

Dasli APE, Muljono P, Susanto J. 2015. Pemanfaatan Cyber Extension melalui Telepon Genggam oleh Petani Anggrek di Taman Anggrek Ragunan Jakarta Selatan. Bogor (ID): Jurnal Penyuluhan, 11(2) : $1-10$.

Fitri S. 2017. Dampak Positif dan Negatif Sosial Media terhadap Perubahan Sosial Anak. Naturalistic: Jurnal Kajian Penelitian Pendidikan dan Pembelajaran 1(2) : 118-123.

Fahriantini E. 2016. Peranan Orangtua dalam Pengawasan Anak pada Penggunaan Blackberry Messenger di Al Azhar Syifa Budi Samarinda. eJournal Ilmu Komunikasi, 2016: 4(4): 44-55.

Faisal N. 2016. Pola Asuh Orang Tua dalam Mendidik Anak di Era Digital. Jurnal An-Nisa, IX(2) : 121137. [Internet]dapat diunduh di http://e-jurnal. stainwatampone.ac.id/index.php/an-nisa/article/ viewFile/191/184

Peter R. 2015. Peran Orangtua dalam Krisis Remaja. Jurnal Humaniora, 6(4): 453-460. [Internet] dapat diunduh di http://oaji.net/ articles/2015/2639-1448598526.pdf
John B, Thavavel V, Jayaraj J, Muthukumar A, Jeevanandam PK. 2016. Design of Open Content Social Learning that Increases Learning Efficiency and Engagement Based on Open Pedagogy. TOJET: The Turkish Online Journal of Educational Technology, 15(1) : 20-32.

Juwita EP, Budimansyah D, Nurbayani D, Siti. 2015. Peran Media Sosial terhadap Gaya Hidup Siswa SMA Negeri 5 Bandung. Bandung (ID): Jurnal Sosietas, 5(1) . [Internet] dapat diunduh di http://ejournal.upi.edu/index.php/sosietas/issue/ view/181

Kemkominfo. 2014. Pengguna Internet di Indonesia Capai 82 Juta. [Internet] dapat diunduh di https:// kominfo.go.id/index.php/content/detail/3980/0\%

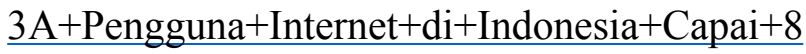
2+Juta/0/berita satker

Kominfo. 2014. Riset Kominfo dan UNICEF Mengenai Perilaku Anak dan Remaja dalam Menggunakan Internet Siaran Pers No.17/PIH/ Kominfo/2/2014. [Internet] dapatdinduhdihttps:// kominfo.go.id/index.php/content/detail/3834/ Siaran+Pers+No.+17-PIH-KOMINFO-2014+te ntang + Riset + Kominfo + dan+UNICEF + Mengena $\underline{\mathrm{i}+\text { Perilaku}+ \text { Anak }+ \text { dan }+ \text { Remaja }+ \text { Dalam }+ \text { Mengg }}$ unakan+Internet $+/ 0 /$ siaran pers

Kusuma N, Hadiyanto. 2015. Perilaku Menonton dan Kepuasan Petani terhadap Program Merajut Asa di Televisi TV Trans7. Bogor (ID): Jurnal Penyuluhan, 11(1) : $60-68$.

Nugraha AM, Suryadi, Syam K, Syam S. 2015. Penggunaan Media Sosial Path Sebagai Sarana Pengakuan Sosial. Bandung (ID): Jurnal Pendidikan Sosiologi, UPI Bandung. Jurnal Sosietas, 5(2).

Siyamitri P. 2015. Literasi Media Internet pada Kalangan Guru Sekolah Menengah Kejuruan di Kota Medan. Jurnal Simbolika, 1(2) : 161-175.

Susena E, dkk, Dewi A. 2014 Dampak Penggunaan Internet terhadap Kecerdasan Pelajar Sekolah Menengah Atas di Daerah Pedesaan dalam Rangka Peningkatan Kualitas Pendidikan di Daerah Pedesaan. Surakarta (ID): Jurnal Sainstech Politeknik Indonusa Surakarta, 1(2) : 1-10. [Internet] dapat diunduh di http:// www.poltekindonusa.ac.id/wp-content/ uploads/2016/05/Vol-1-2-2014-DampakPenggunaan-Internet-Terhadap-KecerdasanPelajar-Edy-Susena.pdf 
Jurnal Penyuluhan, Maret 2018 Vol. 14 No. 1

Ulinuhha M. 2013. Melindungi Anak dari Konten Negatif Internet; Studi terhadap Peramban Web Khususnya Anak. Jurnal Sawwa, 8(2) : 341-360. Youthmanual. 2017. Data Pengguna Internet Tahun 2017. [Internet] dapat diunduh di https://www. youthmanual.com/post/fun/did-you-know/ data-pengguna-internet-tahun-2017-dan-apakesimpulan-yang-bisa-diambil-dari-datatersebut. 